\title{
Trophic cascades from wolves to alders in Yellowstone
}

4

$15{ }^{1}$ Corresponding author:

16 bill.ripple@oregonstate.edu

$17 \quad$ Phone 5417373056

$18 \quad$ fax 5417371393

\author{
William J. Ripple ${ }^{1}$, Robert L. Beschta ${ }^{1}$, Luke E. Painter ${ }^{2}$ \\ ${ }^{1}$ Department of Forest Ecosystems and Society \\ Oregon State University \\ Corvallis, Oregon 97331 USA \\ ${ }^{2}$ Department of Fisheries and Wildlife \\ Oregon State University \\ Corvallis, Oregon 97331 USA
}




\section{Abstract}

20 We explored possible interactions among gray wolves (Canis lupus), Rocky Mountain

21 elk (Cervus elaphus), and thinleaf alder (Alnus incana spp. tenuifoli) in northern Yellowstone

22 National Park. We developed an alder age structure based on annual growth rings for plants

23 growing along six streams in areas accessible to ungulates on the northern range. Alder stems

$24(n=412)$ along the six streams originated only after wolf reintroduction. By $2013,80 \%$ of the

25 sampled alders along these streams were taller than $2 \mathrm{~m}$, in contrast with a historical pattern of

26 height suppression by ungulate herbivory. This pattern of alder recruitment is consistent with a

27 trophic cascade whereby new alder growth occurred across all study streams within several years

28 after wolf reintroduction. Although declines in elk density since wolf reintroduction likely

29 contributed to the release of alder from herbivory, the immediate onset of new alder recruitment

30 following wolf reintroduction indicates that behavioral responses to predation may also have

31 been an important component in the resulting trophic cascade. These results suggest that predator

32 conservation could play a role in the management and ecological restoration of riparian areas.

36 Key Words: wolves, alder trees, elk, Yellowstone, trophic cascades, riparian 


\section{Introduction}

The removal of large carnivores from much of the world has had diverse ecological

39 effects, often revealed through unexpected and complex interactions (Terborgh and Estes, 2010;

40 Ripple et al., 2014b). One example of predator effects occurs in trophic cascades, where the

41 effects of predators on prey are translated downward and across food webs (Estes et al., 2011).

42 Yellowstone National Park (YNP) has been the focus of recent research on trophic cascades

43 involving the extirpation and repatriation of gray wolves (Canis lupus) and represents a large-

44 scale natural experiment that provides a unique opportunity to examine the interplay between

45 predators, prey, and plants.

After wolves were extirpated from YNP in the mid-1920s, park biologists became

47 concerned about the effects of increased Rocky Mountain elk (Cervus elaphus) browsing on

48 vegetation in the northern and Gallatin ungulate winter ranges (Skinner, 1928; Rush, 1932;

49 Wright et al., 1933; YNP, 1958; Lovaas, 1970; Ripple and Beschta, 2006). Analyses of the

50 annual growth rings of deciduous tree species revealed that recruitment (i.e., growth of

51 seedlings/sprouts into tall saplings or trees) occurred regularly in both of these YNP winter

52 ranges when wolves were present, but declined and became rare after wolf extirpation (Ripple

53 and Larsen, 2000; Beschta, 2005; Halofsky and Ripple, 2008a; Kauffman et al., 2010). These

54 tree-ring study results are consistent with reports of YNP biologists (as cited above) about the

55 decline of woody browse species in the early and middle $20^{\text {th }}$ century. As a result of park service

56 biologists' concerns, a program of elk reductions was initiated in the 1930s and continued

57 through 1968. By the late 1960s, park service culling had reduced the northern range elk

58 population to less than 5,000 individuals (Figure 1a), but with no resulting major recovery in

59 recruitment of woody plants (Houston, 1982; Kay, 1990; Meagher and Houston, 1998; NRC, 
60 2002; Barmore, 2003). After the elk culling program ended in 1968, elk numbers increased 61 dramatically during the 1970s (Figure 1a). In the 1980s and 1990s, elk numbers fluctuated

62 widely due to winter starvation events (Garrott et al., 2003; Eberhardt et al., 2007). During this

63 period of large population size (>19,000 elk in some years on the northern range), elk were

64 limited by food resources and consumed relatively unpalatable species such as conifers (Kay,

65 1990; Meagher and Houston, 1998; NRC, 2002).

66 Wolves were reintroduced into YNP during 1995-96 following approximately seven

67 decades of absence (Figure 1b). Thirty-one wolves were moved from Canada to the northern

68 range of YNP in January $1995(n=14)$ and January $1996(n=17)$. By 1996, five wolf pack

69 territories covered nearly all of the northern range within the park (Figure S1 in supplement,

70 Figure 1 in Philips and Smith 1997). During the fall of 1996, each of three different wolf packs

71 on the northern range killed, on average, 1 elk every 2-3 days (Phillips and Smith, 1997).

72 Following reintroduction, wolf numbers on the northern range increased until 2003 and

73 thereafter declined, while the elk population decreased steadily during this period (Figure 1a-b).

74 The initial decline in elk numbers in the mid-to-late 1990s was due in part to starvation caused

75 by a severe winter in 1996-97; other factors included predation by wolves, bears, and continued

76 hunting by humans of elk that left the park (Eberhardt et al., 2007; White and Garrott, 2013).

77 Research on the effects of predators, ungulates, and other factors on the establishment

78 and growth of deciduous trees in northern Yellowstone has focused on aspen (Populus

79 tremuloides) and cottonwood trees (Populus spp.) (reviewed by Ripple and Beschta, 2012).

80 Recruitment of these tree species has increased since the reintroduction of wolves, although the

81 magnitude of the recovery is spatially variable (Beschta and Ripple, 2014; Painter et al., 2015).

82 Over the same period, deciduous shrubs in some areas of northern Yellowstone have increased in 
83 height, biomass, or cover including willows (Salix spp.) (Beyer et al., 2007; Tercek et al., 2010;

84 Baril et al., 2011; Marshall et al., 2014) and various berry-producing shrubs (Beschta and Ripple,

85 2012; Ripple et al., 2014a).

86 Herein we report on the first extensive field study of thinleaf alder (Alnus incana spp.

87 tenuifoli) in Yellowstone's northern range. Thinleaf alder, a small tree or tall shrub, commonly

88 occurs in riparian areas throughout western North America and can grow up to $\sim 12 \mathrm{~m}$ tall (Fryer,

89 2011). Through its nitrogen fixing properties, it enriches soil and facilitates the establishment of

90 other native plants. Thinleaf alder spreads both vegetatively and from small winged seeds,

91 although vegetative reproduction is thought to be more common. It sprouts primarily from root

92 crowns, but can also sprout from roots. Dense alder thickets can provide cover for fish, thermally

93 modify microclimates and stream temperatures via shading, and protect streams from bank

94 erosion. Songbirds eat thinleaf alder seeds, squirrels consume catkins, beaver use stems to build

95 lodges and dams, and various small and large mammals use alder as cover (Fryer, 2011).

96 Thinleaf alder has low palatability as ungulate forage, but it is consumed by ungulates especially

97 when other forage is limited (Gaffney, 1941; Nelson and Leege, 1982; Case and Kauffman,

98 1997). Northern Yellowstone alders, as well as conifers, were affected by browsing in the 1950s

99 (Jonas, 1955) indicating that elk were using low-quality forage even with densities lower than

100 those of the 1980s-90s. Also, before wolf reintroduction Keigley (1997) observed heavy

101 herbivory effects on various woody browse species on the northern range, including alder.

102 Because little is known about Yellowstone's thinleaf alder, our main objective was to

103 analyze temporal patterns of thinleaf alder stem establishment on the northern range of

104 Yellowstone National Park. In light of previous research showing changes in cottonwood and 
105 aspen recruitment following wolf reintroduction, we hypothesized that thinleaf alder exposed to

106 ungulate browsing would also increase in recruitment over this same time period.

108 Methods

109 This study took place on the northern ungulate winter range, comprising more than 1,500

$110 \mathrm{~km}^{2}$ of mountainous terrain and open valleys, approximately two-thirds of which occurs within

111 the northeastern portion of YNP in Wyoming (NRC, 2002). Much of the winter range is shrub

112 steppe, with patches of intermixed lodgepole pine (Pinus contorta), Douglas fir (Pseudotsuga

113 menziesii), Engelmann spruce (Picea engelmanni), and aspen. Thinleaf alder, and various species

114 of willow, cottonwood, and other woody browse plants occur within riparian zones. See Houston

115 (1982) and NRC (2002) for a more detailed description of the northern range study area.

116 We determined the age structure of alder (frequency distribution of number of stems by

117 year of establishment) growing along small streams, and then compared the number of alder

118 stems established before wolf reintroduction versus after wolf reintroduction. This research

119 design provided two predator treatments: 1) wolves absent (pre-1995) followed by 2) wolves

120 present (post-1995).

121 We located small perennial streams $\left(4^{\text {th }}-5^{\text {th }}\right.$ order $)$ on the northern range within the park

122 that intersected the North Entrance road, the Grand Loop, and the Northeast Entrance road. We

123 excluded streams where riparian areas had burned in the large fires of 1988 (i.e., Lava, Lupine,

124 Elk, Lost, and Tower Creeks). For the remaining streams (Glen, Blacktail, Oxbow, Geode,

125 Crystal, Rose, Indian, and Pebble Creeks), we searched for alder 1,000 m upstream and

126 downstream of the road. We found alder along six of these streams: Blacktail, Oxbow, Geode,

127 Crystal, Rose, and Pebble Creek representing a west-east gradient across the northern range. All 
128 six streams intersect the main west-east road and were within the central and eastern portions of

129 the northern range within the park (Figure 2).

130 Within the search area associated with each of the six streams, we measured the diameter

131 at breast height $(\mathrm{DBH}, \mathrm{cm})$ of the tallest stem of each alder plant (breast height $=1.4 \mathrm{~m})$. We

132 measured only plants that were accessible to ungulate browsing; this excluded any individuals

133 growing in or adjacent to woody debris that might inhibit ungulate access. From each of the six

134 riparian areas we haphazardly selected four alder stems (24 total stems mostly from the larger

135 size classes) to develop an age/diameter regression equation. The larger size classes were more

136 frequently sampled because, as the first recruits, they would be the most critical in determining

137 when any increase in alder growth began to occur. We cut the selected stems at $1.4 \mathrm{~m}$ above the

138 ground level with a hand saw and counted the number of growth rings in the field using a hand

139 lens after sanding the sections. From this set of data we developed an age/diameter relationship

140 equation with $95 \%$ confidence intervals (CI). To determine the number of years it took for alder

141 stems to reach breast height, we haphazardly located alder stems $\sim 1.4 \mathrm{~m}$ tall along our stream

142 study reaches and aged them by counting the number of annual bud scars along the stems. Both

143 of these approaches, the age/diameter regression and the counting of bud scars, were undertaken

144 to minimize destructive sampling because alder were not abundant at our study sites.

145 We determined the distance to the nearest road for each measured alder. We tested for a 146 road effect because of the potential for road disturbance to affect ungulate behavior, although our 147 previous work in northern Yellowstone showed no effect of roads on the amount of elk browsing 148 (Ripple and Beschta, 2007). We used regression analysis to inspect for a significant relationship 149 between distance to roads and alder size classes. 
151 courses. Annual snowpack accumulations can influence ungulate foraging and predation rates in

152 winter (Garrott et al., 2009) and low snowpacks can exacerbate summer drought conditions. To

153 index snow conditions in northern YNP, we obtained SWE data (January 1-April 1) for the

154 Lupine Creek and Northeast Entrance snow-recording locations (data obtained from USDA

155 National Resource Conservation Service); these locations are $\sim 48 \mathrm{~km}$ apart and bracket our study

156 sites. From these data we calculated the average annual SWE for the period 1960-2008. We also

157 calculated the long-term average SWE and compared SWE for the years before and after wolf

158 reintroduction to this mean.

160 Results

161 We measured the DBH of 412 ungulate-accessible alders along the six study streams and

162 found only young saplings $(\mathrm{DBH}$ range $=0.2-5.2 \mathrm{~cm}$ ) with no larger overstory alders. The $\mathrm{DBH}$

163 of the 24 sectioned alder stems included $<2 \mathrm{~cm}(\mathrm{n}=3), 2-3 \mathrm{~cm}(\mathrm{n}=4), 3-4 \mathrm{~cm}(\mathrm{n}=5)$, and 4-5

$164 \mathrm{~cm}(\mathrm{n}=12)$. We evaluated linear and non-linear age/DBH relationships for least squares fit. We

165 selected a linear model because non-linear models where not significantly better fits than the

166 linear model $\left(\log\right.$ transformed $r^{2}=0.70$, quadratic $r^{2}=0.77$, and power function $\left.r^{2}=0.78\right)$. The

167 linear age-DBH relationship was: age $=2.55 \times \mathrm{DBH}\left(\mathrm{r}^{2}=0.75, \mathrm{p}<0.001, \mathrm{n}=24\right)$. For our

168 largest measured alder stems of $5.2 \mathrm{~cm} \mathrm{DBH}$, the regression predicted age was 13.3 years $(95 \%$

$169 \mathrm{CI} \pm 0.9$ years). The linear regression was applied to all measured alders stems for determining

170 dates of establishment. The average age of stems at breast height was 4 years $(n=17,95 \% \mathrm{CI} \pm$

171 0.2). Establishment year (EY) for individual stems was estimated as follows: $E Y=2013-(2.55$

$172 \mathrm{x} \mathrm{DBH})+4$ years. 
Our analysis indicates that alder stems growing along the six study streams originated

174 from approximately1996 through 2008 (Figure 3). Age estimates of the oldest alder stems (i.e.,

175 1996, Figure 3) had a 95\% CI of \pm 0.9 years, indicating the initial onset of alder growth most

176 likely occurred around 1995-97. Alder stems originating since 2008 were too small for obtaining

177 DBH measurements. In 2013, $80 \%$ of the measured alders along the study streams were taller

178 than $2 \mathrm{~m}$, generally considered to be above the normal browse level of elk (Figure 4). We do not

179 know the proportion of alder stems that established from seeds versus roots in our study sites, but

180 in some cases we observed that visible old root systems were the obvious source of stem

181 establishment.

182 There was no significant relationship between distance to road and alder stem diameter

183 size $\left(\mathrm{r}^{2}<0.01, \mathrm{p}=0.55, \mathrm{n}=412\right)$. SWE was above average for the two years immediately

184 following wolf reintroduction (1996-97; Figure 5). However, the annual SWE was below

185 average most years after 1997, consistent with the fact that the region was in a drought (Painter

186 et al., 2014).

188 Discussion

189 To the best of our knowledge, our results for alder represent the first published study of

190 this woody species in Yellowstone's northern range, and the first to evaluate the possible effects

191 of wolf reintroduction on alder. Comparing alder recruitment rates before and after wolf

192 reintroduction, provides an important tool for understanding temporal patterns of alder

193 recruitment. Furthermore, our survey of alder across much of the northern range of Yellowstone

194 allows for a broad scope of inference within the range. Below we discuss our results in the

195 context of trophic cascades, whether behaviorally or density-meditated, and also consider climate 
196 fluctuations as a possible explanation (alternative hypothesis) for new recruitment and increased 197 alder height.

199 Trophic Cascades

200 Our results are consistent with the hypothesis of a wolf-ungulate-alder trophic cascade in 201 northern Yellowstone, supported by comparisons of alder age structure across time, before and 202 after wolf reintroduction at our study sites. This evidence demonstrates that alder stems recruited 203 only after wolf reintroduction at our study sites. Thus, alder recruitment was likely linked to 204 changes in top-down forces (reduced ungulate browsing).

205 Our finding that alder recruitment was rare or absent before wolf reintroduction, and 206 greatly increased thereafter, is consistent with other studies on the northern range that found 207 decreased herbivory and increased growth of aspen, cottonwood, willow and various berry208 producing shrubs (Beyer et al., 2007; Tercek et al., 2010; Beschta and Ripple, 2014; Painter et 209 al., 2014; Ripple et al., 2014a; but see Kauffman et al., 2010). Along some streams on the 210 northern range, riparian willow, cottonwood, and aspen started growing taller by 1997, 2002, and 211 2004, respectively (Ripple and Beschta 2012). Our results also agree with previous research in

212 Yellowstone finding that woody browse species were severely suppressed, particularly in the last

213 decades of the $20^{\text {th }}$ century, a period during which wolves were absent from the area and elk 214 densities were high. By comparing historical photos to modern photos of the northern range, for 215 instance, Meagher and Houston (1998) found that the abundance of woody species decreased 216 during the 20th century.

217 Predators can propagate cascading effects down trophic chains in at least two ways, by 218 changes in prey density or behavior (Preisser et al., 2005). Because these effects can have similar 
219 impacts on prey resources, it can be difficult to determine their relative importance; many trophic 220 cascades likely combine both density and behavioral effects.

221 Density effects. Following the reintroduction of wolves, northern range elk counts

222 dropped from $\sim 19,000$ in 1994 to $\sim 12,000$ in 1998, due in part to the severe winter of $1996 / 97$

223 (Figure 5) (Garrott et al., 2003). Elk counts rebounded to 14,500 by 2000 before declining again

224 to 6,300 counted individuals in 2008. During this time (2000-08), elk numbers in the eastern and

225 central sectors of the northern range decreased more than in the western and northwestern sectors

226 (Painter et al., 2015). The steady reduction in elk numbers and their redistribution within the

227 northern range is evidence that the elk population has been mediated by predation (top-down)

228 following the return of wolves (Hamlin et al., 2009; Creel et al., 2013; White and Garrott, 2013).

229 While researchers have debated the relative importance of factors affecting elk population

230 dynamics, including increased bear predation (Barber-Meyer et al., 2008), large pre-2005

231 hunting harvests (Eberhardt et al., 2007), and a 2000-07 drought (White and Garrott, 2013),

232 wolves have likely played a substantial role in the declining numbers and changing distribution

233 of the northern Yellowstone elk herd (Hamlin et al., 2009). Elk hunting, of those animals that

234 seasonally left the park, was greatly reduced after 2005 and the drought ended by 2007, yet

235 through 2012 elk numbers within the park's northern range continued to decline under pressure

236 from wolves and bears (White and Garrott, 2013; Painter et al., 2015), thus likely contributing to

237 decreased herbivory of alder and other woody plants in recent years.

238 We asked why alder recruitment in the northern range occurred since the late 1990s, but

239 was apparently lacking in the late 1960s when elk numbers at their lowest. It is likely that some

240 woody plant communities in riparian areas, including alder, began growing taller in the late

241 1960s but were subsequently suppressed by browsing and died as elk numbers increased 
242 dramatically after culling ended in 1968. Photographic evidence from the Lamar Valley supports

243 this possibility in that it shows riparian plants starting to recruit in 1969 (Figure. S2).

244 Increased growth of young woody plants in the late 1960s does not explain a lack of alder

245 recruitment in the 1950s when elk numbers (Houston, 1982; Painter et al., 2014) were

246 comparable to those for the period 1998-2003, during which alder recruitment occurred. One

247 possible explanation is that elk distributions were different between these two periods. In the

248 1950s most elk wintered within the park boundary with many in the eastern portion of the range

249 (Houston, 1982). In contrast, elk distribution since wolf reintroduction has shifted west and north

250 (White et al., 2012; Painter et al., 2015), resulting in lower elk densities for our six study sites

251 (i.e., the central and eastern sectors of the northern range) than in the 1950s. This recent

252 redistribution may represent a landscape-scale response of elk to changes in predation risk.

253 Behavioral effects. Prey animals foraging in risky environments must balance conflicting

254 demands for food acquisition and safety (Lima and Dill, 1990; Brown et al., 1999). Predators can

255 elicit a strong behavioral response in the prey population even with limited effects on prey

256 density (Werner and Peacor, 2003; Creel and Christianson, 2008). For example, the foraging

257 reduction by prey due to the presence of a predator can be strong, immediate, and widespread in

258 the population of prey (Schmitz, 1998; Preisser et al., 2005). For prey, the risk of foraging is

259 factored against maximizing the net rate of energy intake (Sih, 1980), but food varies in

260 palatability, as well as nutritional and energetic content.

261 In Yellowstone, numerous researchers have shown that elk respond to the risk of wolf

262 predation by altering their habitat use, movements, group size, vigilance, nutritional intake, and

263 other traits (Laundré et al., 2001; Childress and Lung, 2003; Fortin et al., 2005; Hernandez and

264 Laundre, 2005; Beyer, 2006; Gude et al., 2006; Halofsky and Ripple, 2008b; Christianson and 
265 Creel, 2010). As early as 1996 all of our study sites were within one or more wolf pack

266 territories. The renewal of alder recruitment, a woody plant with low palatability, across all six

267 study streams by the mid-late 1990s (immediately after wolf reintroduction), is consistent with

268 the hypothesis that risk-induced shifts in elk foraging behavior may have contributed to reduced

269 herbivory since elk densities were still relatively high. In contrast, predator-mediated reduction

270 in prey numbers over time should lead to impacts occurring gradually, with the effect size

271 generally related to the proportion of prey population removed (Werner and Peacor, 2003).

272 Because new alder recruitment began soon after wolf reintroduction and occurred over a large

273 portion of the northern range, our results for the years immediately following wolf reintroduction

274 appear consistent with behavioral effects.

275 Though low in palatability, wild ungulates will consume thinleaf alder during winter 276 when forage is scarce (Gaffney, 1941; Nelson and Leege, 1982; Fryer, 2011). In Oregon, wild 277 ungulates negatively affected the heights of thinleaf alder, but not as much as the heights of the 278 more palatable willow and cottonwood (Case and Kauffman, 1997). In a northwest Montana 279 study (Gaffney, 1941), thinleaf alder was characterized as a non-palatable species that elk only 280 consumed when more palatable plants were overbrowsed. Gaffney (1941, p. 449) stated "Use of 281 any of these species [alder and other less-palatable species] indicates an overbrowsed condition 282 of the more palatable plants." Before wolves were reintroduced in 1995-96, young alder on the 283 northern range were likely suppressed by elk browsing (Jonas, 1955; Keigley, 1997), as were 284 other woody browse species (NRC, 2002), consistent with high elk densities and frequent 285 starvation events. Therefore, if risk of predation by wolves after 1995 caused elk to give up some 286 foraging opportunities, it is likely that alder, with low palatability, would have been abandoned 287 before more palatable woody species. 
While both behavior and density mediation may have contributed to the resurgence of

290 alder since 1996, our ability to tease apart the relative importance of each is limited. The fact that

291 ours was an observational study rather than a controlled experiment limits the strength and scope

292 of inferences possible from our results.

293 There may be some error in the alder stem age structure data due to our minimally

294 destructive sampling approaches (age-diameter regression, bud scars). However, any error due to

295 predicting age from diameters is probably small because of the high correlation between alder

296 diameter and age $\left(\mathrm{r}^{2}=0.75\right)$, a narrow $95 \%$ confidence interval $(\mathrm{CI}+0.9$ years $)$ and a regression

297 with an intercept through zero. While estimation errors for age are likely to increase with tree

298 size, the alders we sampled were all small $(\mathrm{DBH}$ range $<=5.2 \mathrm{~cm}$ ) leaving little possibility for a

299 significant error regarding their ages.

$300 \quad$ Alternative Hypotheses

$301 \quad$ An alternative to a trophic cascade mechanism as the cause of increased alder recruitment

302 involves climate change or climatic fluctuations. In this scenario, alder recruitment might

303 improve due to factors such as a longer growing season, increased water availability, or deep

304 snow that could protect plants from browsing and force elk to abandon high-elevation parts of

305 the range. While the length of an average growing season in the region has increased slightly

306 (Wilmers and Getz, 2005), the impact of this change on plants should be gradual rather than

307 abrupt (i.e., the abrupt occurrence of alder recruitment post-1995; Figure 3). Increased water

308 availability is also an unlikely explanation since a regional drought occurred during 2000-07

309 (White and Garrott, 2013; Painter et al., 2014), and we detected no alder recruitment in the 1970s

310 which was a period of greater moisture and relatively low elk densities. Although the deep snow 
311 in winter of 1996-97 may have temporarily protected alder from herbivory, snow accumulations

312 were below average for most of the first decade following wolf reintroduction (Figure 5). It

313 should also be noted that previous high snowfall years in the absence of wolves before 1995

314 (Figure 5) had no apparent effect on alder recruitment (Figure 3).

\section{Conclusion}

317 The resumption and increase after 1995 of thinleaf alder recruitment in portions of

318 northern YNP is consistent with a trophic cascade involving wolves, ungulates, and alder,

319 mediated by a combination of behavioral and density effects. The timing of the onset of alder

320 recruitment was nearly coincidental with wolf reintroduction, which suggests that behavioral

321 mediation was a factor. However, the potential importance of this mechanism in recent years has

322 been obscured by major shifts in elk habitat use across the northern range as well as a downward

323 trend in elk numbers (density mediation). With the possible exception of any effects associated

324 with the 1996-97 high snowfall, increased alder recruitment following wolf reintroduction was

325 unlikely to have been caused by climate fluctuations or trends, as the recruitment continued

326 through a decade of drought and low snowfall. The observed patterns of alder recruitment

327 provide additional evidence of the far-reaching effects of predators and their prey on the

328 structure and functioning of Yellowstone's ecosystem. The response of alder following the return

329 of wolves suggests that predator conservation could be part of a management strategy to restore

330 riparian areas and enhance biodiversity where forage plants have been suppressed by herbivores. 
334 Agriculture, United States Department of Agriculture, McIntire-Stennis Funds under ID number

335 OREZ-FES-846-S. We thank Sandie Arbogast for assistance in developing the graphics for the

336 figures. We also appreciate the comments made by Evan Preisser on an early draft and assistance 337 on statistical analysis by Christopher Wolf.

\section{References}

340 Barber-Meyer, S.M., Mech, L.D., White, P.J., 2008. Elk calf survival and mortality following wolf restoration to Yellowstone National Park. Wildlife Monographs 169, 1-30.

342 Baril, L.M., Hansen, A.J., Renkin, R., Lawrence, R., 2011. Songbird response to increased willow (Salix spp.) growth in Yellowstone's northern range. Ecological Applications 21, 2283-2296.

Barmore, W.J., 2003. Ecology of Ungulates and their Winter Range in Northern Yellowstone National Park; Research and Synthesis 1962-1970. Yellowstone Center for Resources,

348 Beschta, R.L., 2005. Reduced cottonwood recruitment following extirpation of wolves in Yellowstone's northern range. Ecology 86, 391-403.

350 Beschta, R.L., Ripple, W.J., 2012. Berry-producing shrub characteristics following wolf reintroduction in Yellowstone National Park. Forest Ecology and Management 276, 132138.

353 Beschta, R.L., Ripple, W.J., 2014. Divergent patterns of riparian cottonwood recovery after the return of wolves in Yellowstone, USA. Ecohydrology doi:10.1002/eco.1487. 
Beyer, H.L., 2006. Wolves, elk and willow on Yellowstone National Park's northern range. M.S. Thesis. University of Alberta, Edmonton.

357 Beyer, H.L., Merrill, E.H., Varley, N., Boyce, M.S., 2007. Willow on Yellowstone's northern range: evidence for a trophic cascade? Ecological Applications 17, 1563-1571.

Brown, J.S., Laundré, J.W., Gurung, M., 1999. The ecology of fear: optimal foraging, game theory, and trophic interactions. Journal of Mammalogy 80, 385-399.

Case, R.L., Kauffman, J.B., 1997. Wild ungulate influences on the recovery of willows, black cottonwood and thin-leaf alder following cessation of cattle grazing in northeastern Oregon. Northwest Science 71, 115-126.

Childress, M.J., Lung, M.A., 2003. Predation risk, gender and the group size effect: does elk

Christianson, D., Creel, S., 2010. A nutritionally mediated risk effect of wolves on elk. Ecology

Eberhardt, L.L., White, P.J., Garrott, R.A., Houston, D.B., 2007. A seventy-year history of trends in Yellowstone's northern elk herd. Journal of Wildlife Management 71, 594-602.

Estes, J.A., Terborgh, J., Brashares, J.S., Power, M.E., Berger, J., Bond, W.J., Carpenter, S.R., Essington, T.E., Holt, R.D., Jackson, J.B.C., Marquis, R.J., Oksanen, L., Oksanen, T., Paine, R.T., Pikitch, E.K., Ripple, W.J., Sandin, S.A., Scheffer, M., Schoener, T.W., 
Shurin, J.B., Sinclair, A.R.E., Soule, M.E., Virtanen, R., Wardle, D.A., 2011. Trophic downgrading of planet Earth. Science 333, 301-306.

Fortin, D., Beyer, H.L., Boyce, M.S., Smith, D.W., Duchesne, T., Mao, J.S., 2005. Wolves influence elk movements: Behavior shapes a trophic cascade in Yellowstone National

Fryer, J.L., 2011. Fire Effects Information System: Alnus incana. Website. USDA Forest Service, Rocky Mountain Research Station, Fire Sciences Laboratory. http://www.fs.fed.us/database/feis/

Gaffney, W.S., 1941. The effects of winter elk browsing, South Fork of the Flathead River, Montana. Journal of Wildlife Management 5, 427-453.

Garrott, R.A., Eberhardt, L.L., White, P.J., 2003. Climate-induced variation in vital rates of an unharvested large-herbivore population. Canadian Journal of Zoology 81, 33.

Garrott, R.A., White, P.J., Watson, F.G.R. (Eds.), 2009. The Ecology of Large Mammals in Central Yellowstone: Sixteen Years of Integrated Field Studies. Academic Press/Elsevier, Boston.

Gude, J.A., Garrott, R.A., Borkowski, J.J., King, F., 2006. Prey risk allocation in a grazing ecosystem. Ecological Applications 16, 285-298.

Halofsky, J., Ripple, W.J., 2008a. Linkages between wolf presence and aspen recruitment in the Gallatin elk winter range of southwestern Montana, USA. Forestry 81, 195-207.

Halofsky, J.S., Ripple, W.J., 2008b. Fine-scale predation risk on elk after wolf reintroduction in Yellowstone National Park, USA. Oecologia 155, 869-877.

Hamlin, K.L., Garrott, R.A., White, P.J., Cunningham, J.A., 2009. Contrasting wolf-ungulate interactions in the Greater Yellowstone Ecosystem. In: Garrott, R.A., White, P.J., 
Watson, F.G.R. (Eds.), The Ecology of Large Mammals in Central Yellowstone. Academic Press/Elsevier, Boston, pp. 541-577.

Hernandez, L., Laundre, J.W., 2005. Foraging in the "landscape of fear", and its implications for habitat use and diet quality of elk Cervus elaphus and bison Bison bison. Wildlife Biology 11, 215-220.

Houston, D.B., 1982. The Northern Yellowstone Elk: Ecology and Management. Macmillan, New York.

Jonas, R.J., 1955. A population and ecological study of the beaver (Castor canadensis) of Yellowstone National Park. M.S. thesis. University of Idaho.

Kauffman, M.J., Brodie, J.F., Jules, E.S., 2010. Are wolves saving Yellowstone's aspen? A landscape-level test of a behaviorally mediated trophic cascade. Ecology 91, 2742-2755.

412 Kay, C.E., 1990. Yellowstone's northern elk herd: a critical evaluation of the "natural regulation" paradigm. PhD dissertation. Utah State University, Logan.

414 Keigley, R.B., 1997. An increase in herbivory of cottonwood in Yellowstone National Park. Northwest Science 71, 127-135.

416 Laundré, J.W., Hernandez, L., Altendorf, K.B., 2001. Wolves, elk, and bison: reestablishing the "landscape of fear" in Yellowstone National Park, USA. Canadian Journal of Zoology

419 Lima, S.L., Dill, L.M., 1990. Behavioral decisions made under the risk of predation: a review and prospectus. Canadian Journal of Zoology 68, 619-640.

421 Lovaas, A.L., 1970. People and the Gallatin Elk Herd. Montana Fish and Game Department, $422 \quad$ Helena. 
Marshall, K.N., Cooper, D.J., Hobbs, N.T., 2014. Interactions among herbivory, climate, topography and plant age shape riparian willow dynamics in northern Yellowstone National Park, USA. Journal of Ecology 102, 667-677.

Meagher, M.M., Houston, D.B., 1998. Yellowstone and the Biology of Time. Oklahoma State University Press, Norman.

Nelson, J.R., Leege, T.A., 1982. Nutritional requirements and food habits. In: Thomas, J.W., Toweill, D.E. (Eds.), Elk of North America: Ecology and Management. Stackpole books, Harrisburg, pp. 323-367.

NRC (National Research Council), 2002. Ecological Dynamics on Yellowstone's Northern Range. National Academies Press, Washington, DC.

Painter, L.E., Beschta, R.L., Larsen, E.J., Ripple, W.J., 2014. After long-term decline, are aspen recovering in northern Yellowstone? Forest Ecology and Management 329, 108-117.

Painter, L.E., Beschta, R.L., Larsen, E.J., Ripple, W.J., 2015. Recovering aspen follow changing elk dynamics in Yellowstone: evidence of a trophic cascade? Ecology 96, 252-263.

Phillips, M.K., Smith, D.W., 1997. Yellowstone Wolf Project: Biennial Report 1995 and 1996, YCR-NR-97-4. National Park Service, Yellowstone Center for Resources, Yellowstone National Park, Wyoming.

Preisser, E.L., Bolnick, D.I., Benard, M.E., 2005. Scared to death? The effects of intimidation and consumption in predator-prey interactions. Ecology 86, 501-509.

Ripple, W.J., Beschta, R.L., 2006. Linking wolves to willows via risk-sensitive foraging by ungulates in the northern Yellowstone ecosystem. Forest Ecology and Management 230, 96-106. 
Ripple, W.J., Beschta, R.L., 2007. Restoring Yellowstone's aspen with wolves. Biological Conservation 138, 514-519.

Ripple, W.J., Beschta, R.L., 2012. Trophic cascades in Yellowstone: the first 15 years after wolf reintroduction. Biological Conservation 145, 205-213.

Ripple, W.J., Beschta, R.L., Fortin, J.K., Robbins, C.T., 2014a. Trophic cascades from wolves to grizzly bears in Yellowstone. Journal of Animal Ecology 83, 223-233.

Ripple, W.J., Estes, J.A., Beschta, R.L., Wilmers, C.C., Ritchie, E.G., Hebblewhite, M., Berger, J., Elmhagen, B., Letnic, M., Nelson, M.P., Schmitz, O.J., Smith, D.W., Wallach, A.D., Wirsing, A.J., 2014b. Status and ecological effects of the World's largest carnivores. Science 343, doi:10.1126/science.1241484.

Ripple, W.J., Larsen, E.J., 2000. Historic aspen recruitment, elk, and wolves in northern Yellowstone National Park, USA. Biological Conservation 95, 361-370.

Rush, W.M., 1932. The Northern Yellowstone Elk Study. Montana Fish and Game Commission, Helena.

Schmitz, O., 1998. Direct and indirect effects of predation and predation risk in old-field interaction webs. American Naturalist 151, 327-342.

Sih, A., 1980. Optimal behavior: Can foragers balance two conflicting demands? Science 210, 1041-1043.

Skinner, M.P., 1928. The elk situation. Journal of Mammalogy 9, 309-317.

Terborgh, J., Estes, J.A. (Eds.), 2010. Trophic cascades: predators, prey, and the changing dynamics of nature. Island Press.

Tercek, M.T., Stottlemyer, R., Renkin, R., 2010. Bottom-up factors influencing riparian willow recovery in Yellowstone National Park. Western North American Naturalist 70, 387-399. 
468 Werner, E.E., Peacor, S.D., 2003. A review of trait-mediated indirect interactions in ecological 469 communities. Ecology 84, 1083-1100.

470 White, P.J., Garrott, R.A., 2013. Predation: wolf restoration and the transition of Yellowstone

471 elk. In: White, P.J., Garrott, R.A., Plumb, G.E. (Eds.), Yellowstone's Wildlife in

472 Transition. Harvard University Press, pp. 69-93.

473 Wilmers, C.C., Getz, W.M., 2005. Gray wolves as climate change buffers in Yellowstone. PLoS $474 \quad$ Biology 3, e92. doi:10.1371/journal.pbio.0030092.

475 Wright, G.M., Dixon, J.S., Thompson, B.H., 1933. A preliminary survey of faunal relations in 476 national parks. Fauna Series No. 1, National Park Service, US Government Printing $477 \quad$ Office, Washington, D.C.

478 YNP (Yellowstone National Park), 1958. Management plan for northern elk herd, Yellowstone 479 National Park. National Park Service, Mammoth Hot Springs, Wyoming. National Park $480 \quad$ Service, Mammoth Hot Springs, Wyoming. 


\section{List of Figures}

484 Figure 1. Number of counted (a) elk and (b) wolves on the northern range. Not shown for elk are 485 poor count years of $1977,1989,1991$, and 2006. The field sites for this study were all located in 486 the eastern and central sectors of the northern range (as defined by Painter et al. 2015) and the 487 elk counts for these two sectors were summed and shown with circles as a second series in (a). 488 The eastern and central sectors include the portions of the northern range east of and including 489 the Blacktail Creek drainage. Elk data for the eastern and central sectors were not available prior 490 to 1987.

492 Figure 2. Northern ungulate winter range (northern range) study area showing the locations of 493 six riparian study sites.

495 Figure 3. Alder age structure (number of established stems by year) in ungulate-accessible 496 riparian areas along six study streams on the northern range of YNP (Blacktail Deer Creek, $\mathrm{n}=$ 497128 alder; Oxbow Creek, $\mathrm{n}=123$ Geode Creek, $\mathrm{n}=24$; Crystal Creek, $\mathrm{n}=48$; Rose Creek, $\mathrm{n}=$ 498 57; Pebble Creek, $\mathrm{n}=32$ ). Note the absence of stem establishment before wolf reintroduction 499 (vertical scales vary).

501 Figure 4. Photograph of Blacktail Creek's riparian area in September 2013. The tallest alder stem 502 across the stream from the person was $4 \mathrm{~m}$ tall and had a DBH of $3.5 \mathrm{~cm}$. Alder shown here are 503 in the early stages of recovery and will likely get much taller and form dense thickets. Note the 504 well-vegetated streambank and the on-going recruitment of both alder and willows in the 505 background. Photo credit: W. J. Ripple. 
507 Figure 5. Annual average snow water equivalent (SWE) for the Lupine and NE Entrance snow 508 courses on the northern range for the period 1960-2008. The horizontal line indicates overall 509 mean SWE for this period. See text for details. 

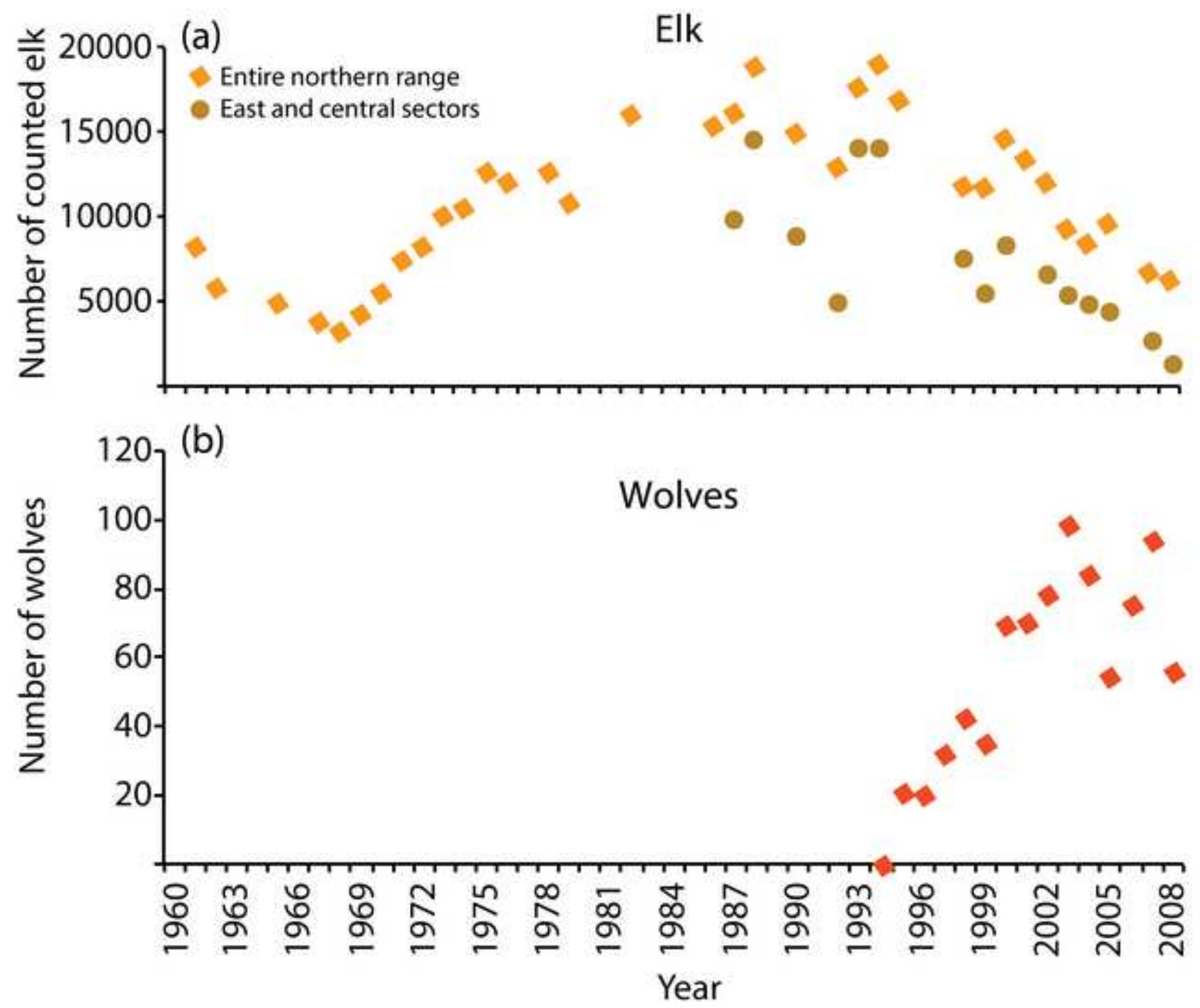


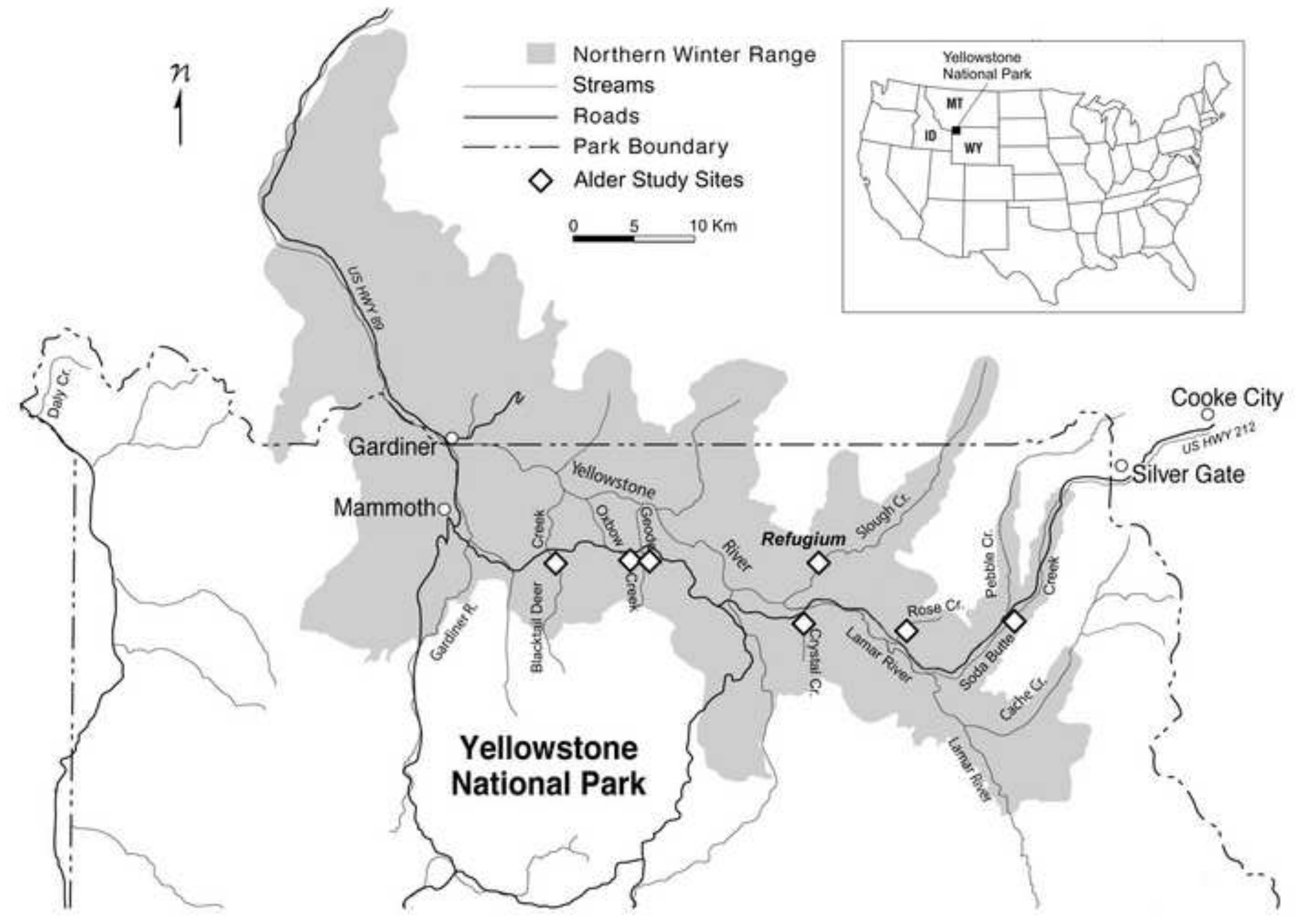


Figure 3

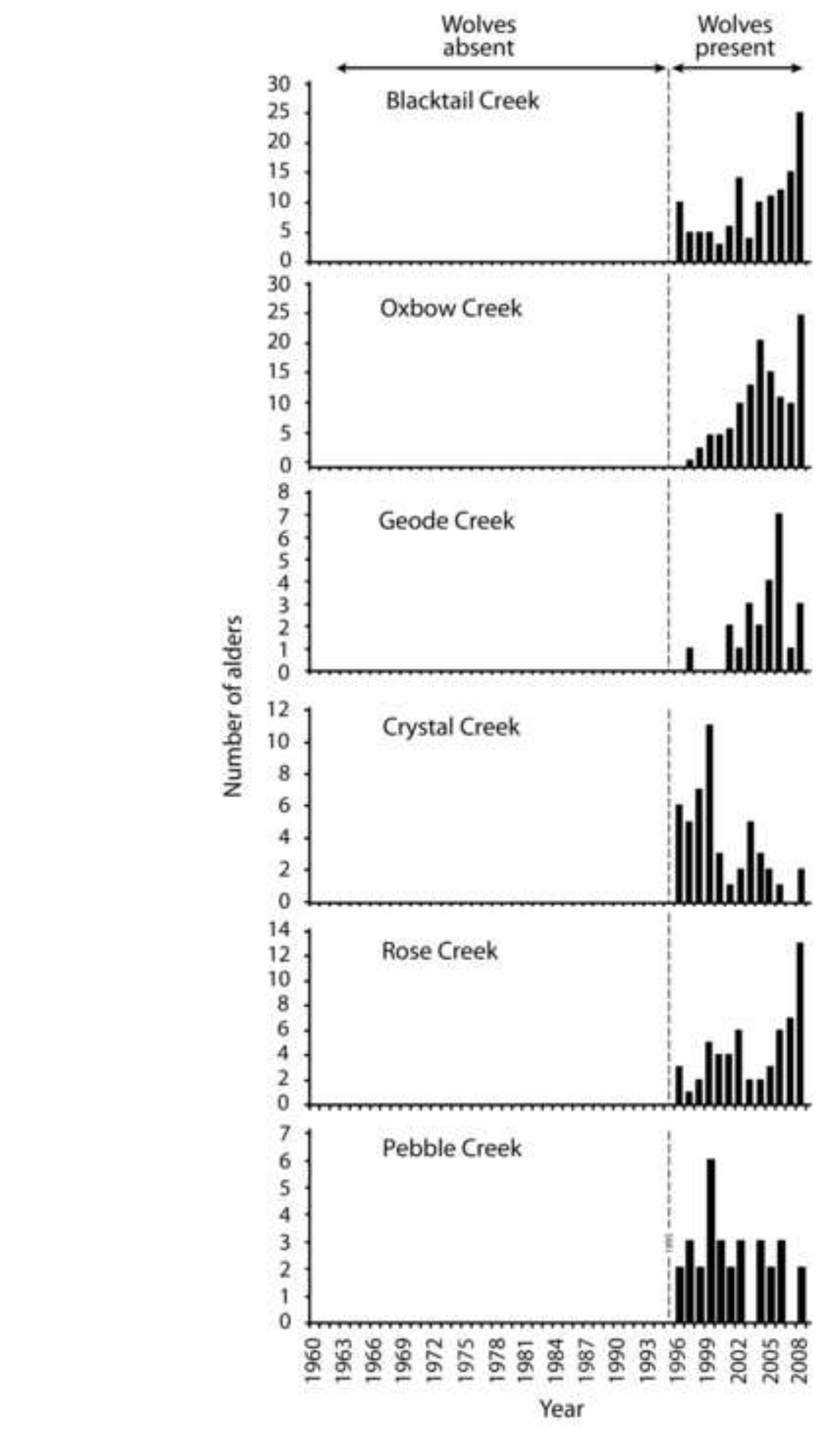

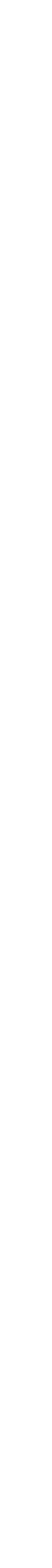

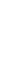




\section{in 3}

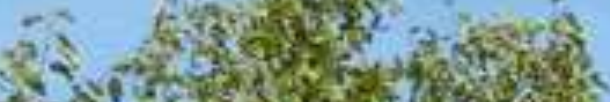

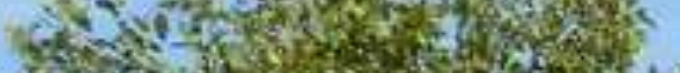

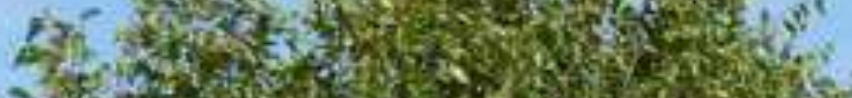

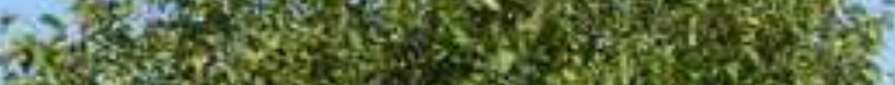

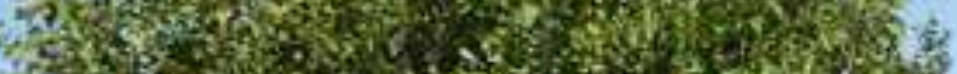

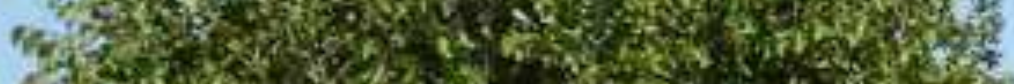

ic

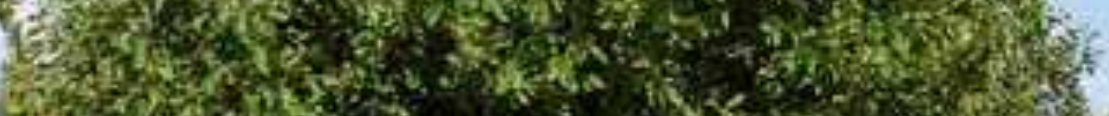

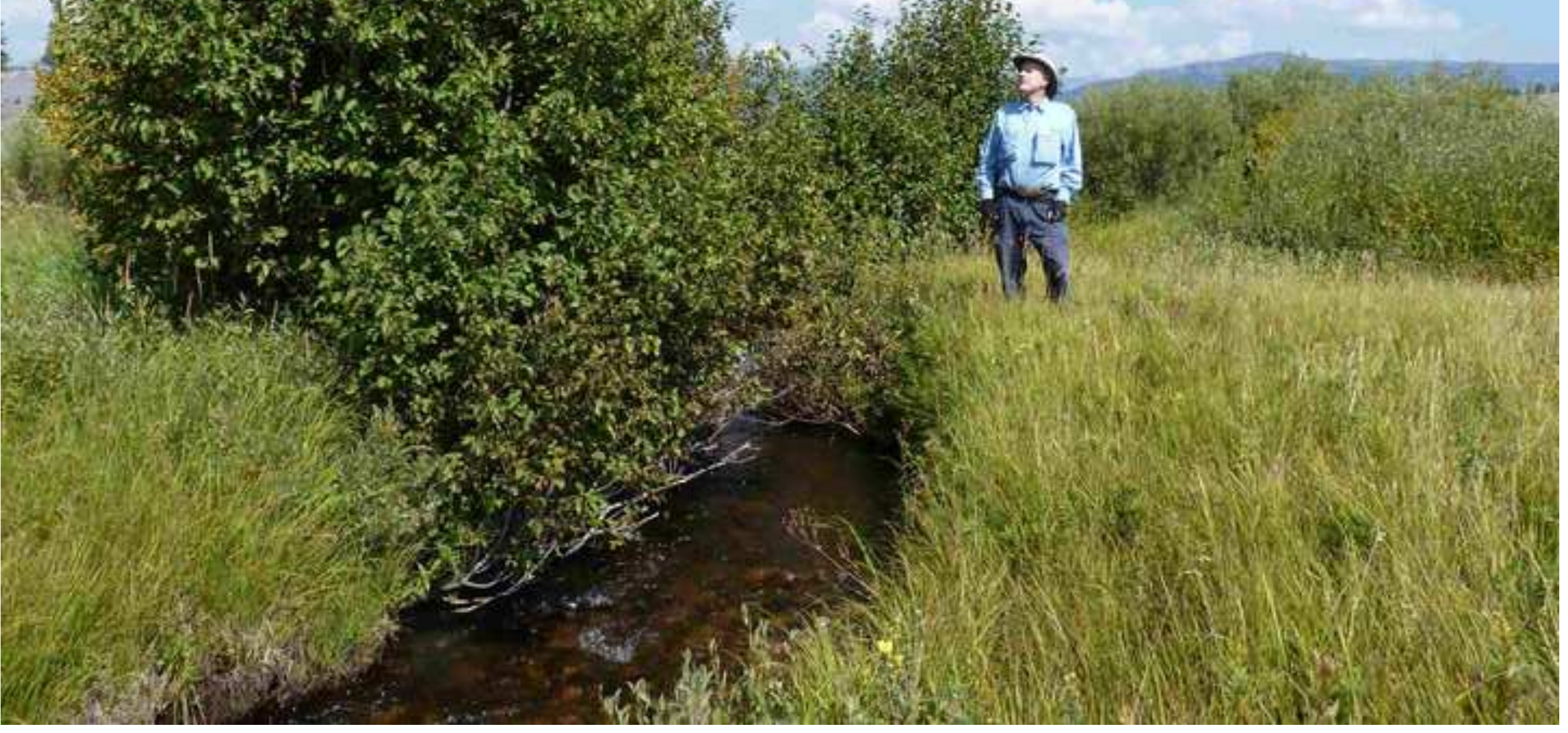




\section{Snow}

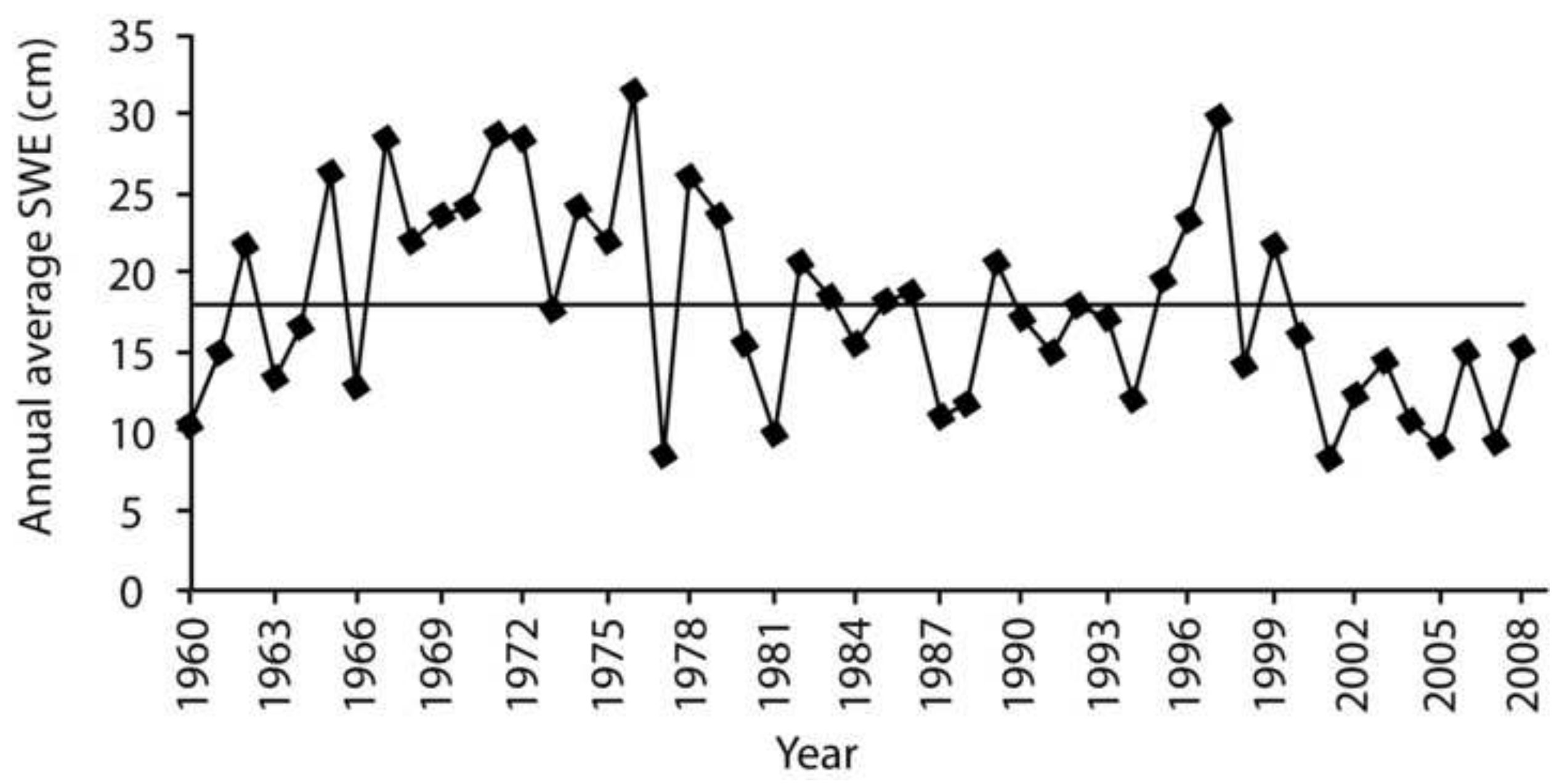

